\title{
МОБИЛИЗАЦИЯ ОБЩЕСТВЕННОГО ПОТЕНЦИАЛА РАБОЧИХ И СЛУЖАЦИК ЗАПАДНОЙ СИБИРИ ПО РЕАБИЛИТАЦИИ РАНЕНЫХ ВОИНОВ КРАСНОЙ АРМИИ В ГОДЫ ВЕЛИКОЙ ОТЕЧЕСТВЕННОЙ ВОЙНЫ
}

Аннотация. В статье рассматриваются общественно-политические настроения рабочих и служащих Западной Сибири, которые проявлялись в заботе и помощи раненым и больным бойцам и командирам Красной армии, отдавшим свои силы и здоровье в борьбе за свободу и независимость Родины. Помощь проявлялась в том, что эвакуированные в Западную Сибирь госпитали были размещены в лучших помещениях, обеспечены передовым в то время оборудованием, укомплектованы высококвалифицированными кадрами.

Рабочие и служащие предприятий, организаций и учреждений, принявшие шефство над госпиталями, организовывали различные мероприятия для помощи раненым и больным воинам и инвалидам. Установлено, что женщины обустраивали быт раненых, дежурили у тяжелобольных, были донорами, бесплатно отдавали свою кровь. Рабочие и служащие проводили воскресники и декадники, чтобы заработанные, а также собранные среди населения деньги, использовать на оказание единовременной помощи, подготовить и вручить подарки каждому воину и инвалиду к знаменательным датам. В госпиталях были созданы условия выздоравливающим солдатам и офицерам совершенствовать боевую и политическую подготовку, чтобы отправиться на фронт. А для инвалидов войны в госпиталях были организованы курсы и мастерские, где они обучались различным специальностям, а органы социальной помощи способствовали их трудоустройству. 
Ключевые слова. Великая Отечественная война, Западная Сибирь, эвакогоспитали, раненые бойцы, командиры Красной армии, инвалиды, шефство, работа в госпиталях, единовременная помощь, подарки, подготовка к мирной жизни.

I. M. Savitskiy Institute of History Siberian Branch of RAS, Novosibirsk, Russian Federation

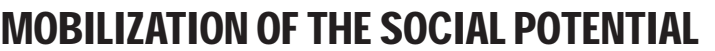

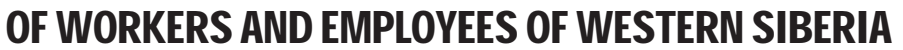

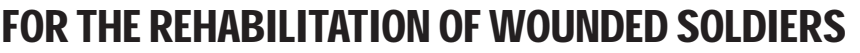

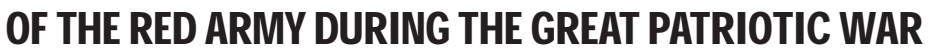

Abstract. The article examines the socio-political sentiments of workers and employees of Western Siberia, which manifested themselves in caring and helping wounded and sick soldiers and commanders of the Red Army who gave their strength and health in the struggle for freedom and independence of the Motherland. The help was shown, for example, through the fact that the hospitals evacuated to Western Siberia were placed in the best premises, provided with the most advanced equipment at that time, staffed with highly qualified personnel.

Workers and employees of enterprises, organizations and institutions that received patronage over hospitals organized various activities to help the wounded and sick soldiers and disabled people. Women that cared for the seriously ill tried to improve the life and donated their blood for free. Workers and employees spent working Sundays and ten-day periods to spent earned and collected money to provide material assistance and to provide gifts to each soldier and disabled person on remarkable dates. In hospitals conditions were created for convalescent soldiers and officers to improve their combat and political training in order to go to the front. And for disabled servicemen courses and workshops were organized in the hospitals where they were trained various specialties. Moreover, the social assistance agencies facilitated their employment. 
Keywords. The Great Patriotic War, Western Siberia, evacuation hospitals, wounded fighters, commanders of the Red Army, disabled people, patronage, work in hospitals, one-time assistance, gifts, preparation for a peaceful life.

В начале Великой Отечественной войны появились раненые бойцы и командиры Красной армии. По решению Правительства СССР в Западной Сибири был создан крупный центр эвакогоспиталей, на лечение в которые прибывали тысячи раненых, больных воинов и инвалидов войны. Все они заслуживали чуткого отношения к себе. Рабочие и служащие Западной Сибири, организации и учреждения шефствовали над госпиталями, проявляли о них заботу и оказывали всемерную помощь им. В это движение включились многие трудящиеся городов региона, особенно женщины, комсомольцы. В результате тысячи воинов восстановили свое здоровье и уезжали на фронт, а инвалиды после лечения вступили в трудовую жизнь. Вместе с тем, в последние годы специальных работ по этой проблеме не опубликовано, и только в последнее время вышла работа М. А. Семенова, которая несколько расширила познания по этой проблеме [6].

В настоящей статье автор предпринял попытку показать различные направления деятельности рабочих и служащих, которые способствовали созданию уюта воинам, особенно помогали тяжелобольным, а инвалидам войны дали возможность получить профессию. Забота и внимание также проявлялась в том, что каждый воин получал подарки к знаменательным датам, которые были созданы на заработанные и собранные среди населения деньги.

Вся работа в стране по обеспечению раненых, находившихся на излечении в госпиталях, возглавлялась Всесоюзным комитетом помощи раненым бойцам и командирам, созданным Государственным Комитетом 
Обороны 22 сентября 1941 г. [3, с. 564]. Правительство СССР для инвалидов Великой Отечественной войны рядового и младшего начальствующего состава определило пенсии в соответствии с уровнем зарплаты, которую они получали до призыва на военную службу. Для тех, кто не работал до войны, пенсия выплачивалась в соответствии с установленной законом. Более высокую пенсию получали инвалиды Отечественной войны, нуждающиеся в следствие потери трудоспособности в особом уходе. Инвалиды войны из кадрового командного и начальствующего состава, сверхсрочнослужащие получали ежемесячную пенсию в зависимости от их денежного оклада в Красной армии.

Партийные и советские организации Западной Сибири развернули сеть эвакогоспиталей, разместив их в лучших зданиях и оснастив хорошим по тем временам оборудованием. С начала Отечественной войны в Омске функционировало 24 госпиталя, размещенные на базе школ, институтов, техникумов, больниц. Укомплектованные лучшими медицинскими кадрами, обеспечены всем необходимым для нормальной работы [3, с. 204].

Наибольшее число эвакуированных госпиталей было развернуто в Новосибирской области, около половины в Западной Сибири. Они были размещены в городах Новосибирске, Томске, Кемерово, Новокузнецке, Прокопьевске, Тайге и др. К 20 января 1942 г. в области размещалось 118 эвакогоспиталей на 628500 коек, что в три раза больше мобилизационного плана.

После разгрома немцев под Москвой и стабилизации линии фронта начался процесс перемещения ряда госпиталей ближе к линии фронта. Через четыре месяца в области осталось 58 эвакогоспиталей на 39650 коек, в два раза меньше. К августу 1943 г. в Новосибирской области насчитывалось 19 эвакогоспиталей на 10350 коек, из них 10 размещались в Новосибирске, 6 - в Томске и три (санаторного типа) - в сельской 
местности. На 16 марта 1945 г. в области осталось 9 эвакогоспиталей, из них 7 в Новосибирске, один - в Бердске и санаторий «Карачи».

В выделившейся Кемеровской области к августу 1943 г. был 21 эвакогоспиталь, а до конца войны просуществовал лишь госпиталь в Новокузнецке.

После образования Томской области в августе 1944 г. в ней насчитывалось шесть эвакогоспиталей, а пять проработали до конца войны [7, с. 121-123].

К 1 января 1942 г. в Алтайском крае было развернуто 76 эвакогоспиталей наркомата здравоохранения на 36600 коек, три госпиталя Наркомата обороны на 1400 коек и три госпиталя ЦК ВЦСПС на 1300 коек, всего 82 эвакогоспиталя на 33300 коек.

Слабость медицинской сети Алтая, нехватка подходящих зданий, неразвитая инфраструктура. По этой причине в период до апреля 1942 г. все эвакуированные в Алтайский край из прифронтовой полосы 54 эвакогоспиталя на 21200 коек были реэвакуированы. Но было получено задание сформировать 8 новых эвакогоспиталей на 8700 коек. На 1 октября 1942 г. в крае находилось 30 эвакогоспиталей Наркомата здравоохранения на 13100 коек, а также госпитали Наркомата обороны и ВЦСПС. В дальнейшем продолжалось сокращение, к 1 января 1945 г. в крае осталось лишь два эвакогоспиталя.

В Омской области к ноябрю 1941 г. за счет эвакуированных выросло число госпиталей до 45. К концу 1942 г. в области осталось 14 на 5800 коек. В начале 1945 г. в Западной Сибири работал всего 21 эвакогоспиталь [7, с. 125-129].

Омский обком ВКП(б) 15 июля 1941 г. принял решение о подготовке госпиталей к приему раненых и больных воинов, в котором обязал областной отдел здравоохранения и другие организации привести в порядок лечебные учреждения, обеспечить персоналом и медикаментами. 8 октября 1941 г. бюро Омского 2018. T. 19, № 1. C. 133-151 
обкома ВКП(б) решило образовать областной комитет по обслуживанию больных и раненых бойцов, и офицеров, который сосредоточил всю работу с ранеными и инвалидами Отечественной войны [4, с. 54]. Создать условия для раненых и больных воинов - это значит содержать их в светлых, чистых и теплых помещениях, обеспечить всем необходимым для лечения, выздоровления и культурного отдыха.

В Омской области для госпиталей были определены лучшие здания, произвели их ремонт, создали для них оборудование. Обеспечили всем необходимым для проживания, лечения и восстановления здоровья. В госпиталях дежурили женщины и молодежь, ухаживали за ранеными, стирали и приводили в порядок одежду и красноармейское снаряжение, убирали палаты и общественные места. Всего в госпиталях было отработано 175 тыс. человеко-дней, из них домохозяйками - более 75 тыс. человеко-дней. 956 сандружинниц принимали активное участие в выгрузке раненых, 280 - работали на санитарных машинах по сопровождению раненых.

По данным на 28 февраля 1943 г. девушки-медсестры и сандружинницы не только оказывали помощь раненым, находившимся в госпиталях, но являлись донорами, отдавали свою кровь бесплатно раненым. В 1944 г. 1312 доноров Красного Креста сдали 310 литров крови. Организациями Красного Креста области в 1944 г. было подготовлено 346 медсестер и 60 чел. санитаров [5, с. 304].

Госпитали были укомплектованы лучшими врачами. В них трудились видные ученые-медики. Так, в госпиталях Томска работал Савиных Андрей Григорьевич, 1888 года рождения - видный ученый хирург, профессор, заведующий кафедрой госпитальной хирургии Томского медицинского института, заслуженный деятель науки РСФСР (1943 г.), лауреат Государственной премии (1943 г.), действительный член Академии медицинских наук СССР (1944 г.). В годы войны 
все силы и знания отдавал делу спасения здоровья и жизни героических защитников Родины. Депутат Верховного Совета СССР трех созывов. Награжден двумя орденами Ленина, орденом Трудового Красного Знамени, медалью «За доблестный труд в Великой Отечественной войне».

Яблоков Дмитрий Дмитриевич, 1886 года рождения, ученый, врач-терапевт, общественный деятель, заслуженный деятель науки РСФСР (1948 г.), член-корреспондент Академии медицинских наук СССР (1950 г.). В годы войны свой многолетний опыт и знания отдавал восстановлению здоровья защитников Родины. Являлся главным терапевтом госпиталей Томска. В 1944 г. ему присуждена Государственная премия за научный труд «Новые лекарственные растения Сибири и их лечебные препараты». Награжден орденом Ленина, двумя орденами Трудового Красного Знамени, медалями «За доблестный труд в Великой Отечественной войне», «За Победой над Германией». Избирался депутатом Верховного Совета РСФСР двух созывов ${ }^{1}$.

В постановлении бюро Томского горкома ВКП(б) 7 января 1943 г. отмечается, что ученые Томска сделали полезные открытия в области военной медицины и профилактики эпидемических заболеваний. Новые бактерициды были открыты профессором Б. П. Токиным, новые методы профессора А. Г. Савиных по хирургии в области грудной клетки, профессора Анохина по лечению травм нервов, эффективная мазь профессора Гольдберга, стимулирующая заживление ран. Написаны монографии по эволюции гистологии профессором Заварзиным, монография Б. П. Токина о новых бактерицидах.

В постановлении бюро горкома акцентировалось: «считать главнейшей задачей томских ученых-ме-

${ }^{1}$ Томская городская партийная организация в годы Великой Отечественной войны : сб. док. и материалов. Томск : Кн. изд-во, 1962. C. 324. 
диков не допустить разрастания эпидемии сыпного тифа, подготовить к весне эффективные средства профилактики инфекционных кишечных заболеваний.

Во всех госпиталях Томска были шефские организации. Некоторые предприятия шефствовали над отдельными палатами. Однако в первые годы войны обстановка в госпиталях складывалась не лучшим образом. Так, в результате проверки состояния работы госпиталя № 1229 было вскрыто антисанитарное состояние. Бюро Томского горкома ВКП(б) обсудило этот вопрос 31 января 1942 г. Комиссар госпиталя Акимов, не обеспечивший его работу, был переведен на нижестоящий участков деятельности. О начальнике госпиталя Клыкове поставлен вопрос о снятии с занимаемой должности. Были отмечены недостатки в работе и других госпиталей. Это решение горкома ВКП(б) обсуждалось на совещании комиссаров, начальников госпиталей и были приняты мероприятия по улучшению в них лечебной и политико-массовой работы ${ }^{3}$.

Предприятия и организации Омской области установили шефство над госпиталями, которое действовало все годы войны. Проявляя заботу о раненых красноармейцах, командирах и политработниках, создавали для госпиталей оборудование, производили ремонт. Шефские организации собрали 1200 тыс. руб. для приобретения и оборудования госпиталей мебелью и хозяйственным инвентарем. Госпиталям было передано большое количество музыкальных инструментов ${ }^{4}$. Исключительную заботу проявляли женщины - шили шторы, изготовляли коврики, обустраивали каждую палату. По данным на 16 сентября 1942 г. шефскими организациями и общественностью Омска для эвакогоспиталей приобретено: 27 роялей и пиани-

2 Томская городская партийная организация в годы Великой Отечественной войны. С. 191-193, 196.

3 Там же. С. 120.

4 Омская правда. 1942.7 нояб. 
но, 17 баянов, 57 гармоней, 215 гитар, 197 мандалин, 328 балалаек, 57 патефонов, 57 репродукторов, 8 широкопленочных киноаппаратов и 13 узкопленочных, большое количество настольных игр и т. д. Общественность города Омска и шефские организации передали госпиталям 62270 книг, из них 36171 - художественной литературы.

Для проведения агитмассовой работы в эвакогоспиталях было подобрано 2490 агитаторов, которые проводили читки газет, художественной литературы для тяжелораненых и больных. Для них было прочитано 798 докладов и лекций, дано концертов и художественных выступлений - 1753, просмотрено 2175 кинокартин [4, с. 226, 227]. Особую активность проявляли комсомольцы, пионеры, школьники. Они выступали с концертами самодеятельности перед ранеными воинами. Омский областной драматический театр и работавшие в Омске эвакуированные театры им. Вахтангова и Запорожский драматический, артисты которых часто встречались с ранеными, устраивали концерты и спектакли. Омский обком профсоюза работников искусств по данным на 1 июля 1942 г. провел в госпиталях 1311 спектаклей и концертов [4, с. 198].

Обком МОПР, осуществляя шефство над палатами госпиталей, вручил раненым воинам подарков на сумму 200 тыс. руб., изготовил 150 шт. теплых вещей, оказал помощь 10 бойцам, вышедшим из госпиталя. Комиссия помощи больным и раненым бойцам, и командирам, по данным Омского отделения Госбанка СССР на 27 октября 1943 г. собрала в 1941 г. 167426 руб., в 1942 г. - 920555 руб., в 1943 г. - 55124 руб.; всего 1143105 руб. [5, с. 117]

По информации Омского горкома ВКП(б) от 15 января 1945 г. в помощь раненым бойцам и командирам было собрано средств: в 1941 г. - 167426 руб., в 1942 г. - 920555 руб., в 1943 г. - 114029 руб., в 1944 г. 990117 руб.; всего - 2192127 руб. [5, с. 206]. Эти средства 2018. T. 19, № 1. C. 133-151 
направлялись на разные цели, в том числе на индивидуальную помощь раненым и на подарки. Раненые и больные воины в эвакогоспиталях получили: новогодних подарков в количестве 8481 шт. на сумму 155279 руб., к 24 годовщине РККА - 9875 подарков на сумму 166699 руб., к 1 мая 1942 г. - 24214 подарков на сумму 214592 руб., к 25 годовщине Октября - 32562 подарка на сумму 879560 руб. [4, с. 56-60].

Кроме того, шефские организации и трудящиеся Омска собрали и предоставили раненым воинам большое количество подарков и денег. За 1942-1943 гг. по далеко не полным данным было передано 189548 подарков на сумму 3199360 руб., вручено именных подарков более чем на 30 тыс. руб. К 26 годовщине РККА находящимся в госпиталях воинам было роздано 25794 кг посылок по линии МОПРа и 137 тыс. руб. [5, с. 209210].

Разнообразная работа по обустройству госпиталей проводилась в Алтайском крае. 14 ноября 1941 г. исполком краевого совета выделил средства на содержание постоянной концертно-эстрадной бригады, которая работала в госпиталях. В решении исполкома Алтайского краевого совета депутатов трудящихся о трудоустройстве и обучении инвалидов Отечественной войны 4 февраля 1942 г. предусматривалось: крайсобесу вместе с начальниками госпиталей развернуть в госпиталях разъяснительную работу по вопросам государственного обеспечения военнослужащих и трудоустройству. Организовать обучение инвалидов Отечественной войны при госпиталях по профессиям: портных, часовых мастеров и другим специальностям пошивка обуви, верхней одежды. В государственных и кооперативных предприятиях, учреждениях и организациях разработать учебно-курсовые мероприятия по обучению инвалидов войны по специальностям: счетоводов, бригадиров колхозов, счетных работников для сберкасс и финорганов, почты, телеграфа, телефо- 
на, портных, столяров, слесарей, сапожников для местной промышленности и кооперативных организаций [1, с. 284].

Исполком обязал руководителей государственных и кооперативных предприятий предоставлять инвалидам Отечественной войны, при наличии заключения врачебно-трудовой экспертной комиссии о пригодности инвалида для работы на производстве, преимущественное право зачисления на работу и создать необходимые условия для освоения инвалидами производственных процессов путем цехового обучения, прохождения техминимума и прикрепления инвалидов к лучшим мастерам. Обеспечивать инвалидов Отечественной войны жилой площадью в первую очередь. Принимать на курсы, профтехшколы и техникумы в первую очередь, ставя органы социального обеспечения в известность о наборе учащихся. Исполком обязывал исполкомы городских, районных советов депутатов обеспечить особый контроль по вопросам обучения и трудоустройства инвалидов Отечественной войны, а также по созданию им жилищных и бытовых условий [1, с. 285].

В целях создания фонда для оказания материальной помощи раненым воинам Отечественной войны в Новосибирске в феврале 1942 г. проведен воскресник. Средства, заработанные на нем, 37 тыс. руб., использовались для помощи прибывающим в отпуск и нуждающимся раненым и инвалидам войны. Раненые и инвалиды Отечественной войны получили возможность приобрести необходимые им вещи - материал на костюм, белье и др. ${ }^{5}$

На 1 января 1944 г. в области было 8100 доноров, в том числе в Новосибирске - 7126. С февраля 1943 г. по 1 января 1944 г. в Томске взято на персональный учет 970 доноров, которые систематически сдавали свою

${ }^{5}$ Государственный архив Новосибирской области (ГАНО). Ф. П-22. Оп. 32. Д. 135. 
кровь. Лучшие доноры: Зимина Александра Прокопьевна сдала 23 литра 600 граммов крови; Савина Мария Ивановна - 9 литров крови; Смирнова Антонина - около 5 литров; Зырянова Акулина Андреевна - около 9 литров. Все они награждены грамотой Новосибирского горисполкома 6 .

При эвакогоспиталях Новосибирска в начале 1942 г. создана сеть производственного обучения раненых бойцов Отечественной войны. Работали группы по обучению сапожному делу, электромонтеров, зоотехников ${ }^{7}$.

26 марта 1943 г. при Томском горкоме ВКП(б) был создан комитет помощи инвалидам Великой Отечественной войны под председательством секретаря горкома по кадрам А. Ф. Мальцева ${ }^{8}$. В отчете Томского городского отдела социального обеспечения за 1 квартал 1943 г. о трудоустройстве и обучении инвалидов Великой Отечественной войны отмечалось, что на 1 апреля 1943 г. работающие инвалиды Отечественной воны III группы составляли 75 \%, вместо 58 \% на 1 марта. Неблагополучные в деле трудоустройства инвалидов Отечественной войны - заводы «Шарикоподшипник» и электромоторный были заслушаны комитетом помощи раненым, который предложил директорам предприятий изменить отношение к трудоустройству инвалидов Отечественной войны и оказании им материальной помощи.

В течение первого квартала 1943 г. в госпиталях было трудообучено 232 чел., в том числе счетоводов (колхозов) - 23 чел., пчеловодов - 19 чел., счетоводов - 91 чел., сапожников - 23 чел., бухгалтеров - 44 чел., подготовлено в техникумы - 14 чел., шоферов 18 чел. Проводилось обучение: агротехников - 15 чел., пчеловодов - 15 чел., сапожников - 18 чел., бухгал-

${ }^{6}$ ГАНО. Ф. П-4. Оп. 78. Д. 252.

7 Там же. Ф. П-22. Оп. 32. Д. 135.

${ }^{8}$ Красное знамя. 1943. 26 марта. 
теров - 27 чел., счетоводов - 27 чел., токарей - 22 чел., слесарей - 32 чел., киномехаников - 14 чел. [8, c. 235-236].

В письме участников совещания передовиков производства Томска воинам 22-й гвардейской стрелковой дивизии 21 января 1944 г. сообщалось, что мы повседневно заботимся о нуждах семей фронтовиков и об инвалидах Отечественной войны. Органами государственного обеспечения и общественными организациями предприятий города была оказана семьям фронтовиков и инвалидам Отечественной войны значительная помощь в ремонте жилья к зиме, в приобретении зимней одежды.

Решением бюро горкома ВКП(б) определено 1000 чел. для обследования и выявления нужд семей фронтовиков и инвалидов Отечественной войны. «Обещаем Вам, сделаем все от нас зависящее, чтобы семьи фронтовиков и инвалиды Отечественной войны чувствовали нашу заботу и внимание» ${ }^{9}$.

За три года войны эвакогоспитали Томска провели большую работу. Вылечили десятки тысяч раненых бойцов и командиров Красной армии, и они вернулись на фронт, а часть из выздоровевших были демобилизованы и включились в трудовую жизнь ${ }^{10}$.

На собрании партийной организации Томского электромеханического завода 16 февраля 1944 г., обсуждая вопрос о шефстве над госпиталем, отмечалось, что был организован сбор подарков раненым воинам, в годовщину РККА 23 февраля не осталось без подарка ни одного раненого бойца и командира Красной армии ${ }^{11}$.

СНК РСФСР 17 апреля 1944 г. принял специальное постановление по вопросу улучшения работы госпи-

9 Томская городская партийная организация в годы Великой Отечественной войны. С. 303-304.

10 Там же. С. 342.

11 Там же. С. 308, 342. 
талей, в котором предупредил о недопустимости снижения заботы о нуждах раненых и больных солдат и офицеров [7].

1 марта 1945 г. директор завода «Томкабель» сообщал Томскому горкому ВКП(б) о том, что его коллектив шефствует на двумя палатами в госпитале № 1248, в которых лечились 13 раненых офицеров и 27 бойцов. Работники завода на подарки им собрали 5875 руб., а также предметы первой необходимости. Каждому офицеру и бойцу был вручен подарок. Завод радиофицировал все палаты госпиталя ${ }^{12}$. Лекторская группа горкома ВКП(б) два-три раза в месяц читала лекции для раненых воинов по важнейшим вопросам международной и внутренней жизни страны. В педагогическом институте была организована лекторская группа, которая читала в госпиталях лекции на исторические и литературные темы. Во всех госпиталях была налажена работа киносети, показывались различные фильмы.

В большинстве госпиталей организованы кружки художественной самодеятельности. Кроме того, в городе действовало 26 бригад художественной самодеятельности по обслуживанию госпиталей. Регулярно проводились их концерты, а также спектакли и выступления артистов городского драматического театра.

Более 700 чел. раненых солдат и офицеров одновременно с лечением совершенствовали знания по боевой и политической подготовке, готовясь вернуться на фронт ${ }^{13}$.

Правительство и местные органы власти уделяли внимание производственному обучению инвалидов Отечественной войны. При многих госпиталях Западной Сибири были организованы специальные курсы, мастерские, где находившиеся на лечении инвалиды

12 Томская городская партийная организация в годы Великой Отечественной войны. С. 400-401.

13 Там же. С. 120-121, 163. 
Отечественной войны могли овладеть профессией согласно состоянию здоровья и освоить трудовые навыки для работы на производстве.

В Томске важную инициативу проявил начальник финансового подразделения госпиталя Нечетный. Он организовал для выздоравливающих бойцов обучение по некоторым специальностям. Занятия начались в сентябре 1941 г. и к 6 октября 1943 г. было подготовлено 25 групп инвалидов войны, получивших разные специальности. В дальнейшем число групп возросло до 344. Бывшие фронтовики приобрели профессии бухгалтеров, счетоводов, пчеловодов, стали заведующими молочных ферм, председателями сельпо и т. д. При госпиталях были организованы мастерские по овладению слесарным, столярным, сапожным делом ${ }^{14}$.

Местные партийные и советские органы Западной Сибири наряду с профессиональным обучением большое внимание уделяли устройству инвалидов войны на работу. Так, в Новосибирской и некоторых других областях сумели устроить на работу почти всех инвалидов третьей группы [3, с. 557]. Так, В. Е. Стародубцев, получивший в госпитале специальность слесаря 3-го разряда, работал в новосибирских производственных мастерских по обучению инвалидов Отечественной войны. В. Кунцевич после ранения поступил работать на Томский электромеханический завод. Овладев профессией слесаря-сборщика, стал тысячником. Участник войны Ушаков, работая на этом же заводе, за короткое время освоил специальность токаря, стал выполнять норму на 250-300 \% .

В Ишимском районе Омской области в 1943 г. среди работников районных учреждений, руководителей колхозов, полеводческих бригад, заведующих фермами трудилось 113 инвалидов Отечественной войны.

14 Томская городская партийная организация в годы Великой Отечественной войны. С. 91. 
Военный отдел Алтайского крайкома ВКП(б) 20 мая 1944 г. сообщал в крайком о ходе выполнения постановления бюро крайкома партии о трудоустройстве и материально-бытовом обеспечении инвалидов Отечественной войны райкомы и горкомы ВКП(б) информировали о принятых мерах. Алтайский район установил всех трудоспособных и устроил всех, кто мог работать. Кроме того, инвалидам войны выдали 280 м мануфактуры, 130 пар валенок, 580 л керосина, 110 куб. м дров и 6 бесплатных путевок на курорты. В Панкрушихинском районе были трудоустроены все способные работать. Инвалиды войны получили 95 м мануфактуры, обеспечены валенками, выдано 347 кг муки, а также мыло и другие принадлежности.

Ойротский обком ВКП(б) сообщал, что инвалидам Отечественной войны выдано более 390 пар валенок, 38 полушубков, 420 летних костюмов и более 1000 м мануфактуры, трудоустроено 1021 чел. В Змеиногорском районе края было 448 инвалидов Отечественной войны, из них офицеров - 47 чел. Трудоустроено 320 чел., из них на руководящую работу, в том числе председателями колхозов - 32 чел., председателями сельсоветов - 5 чел. Проверка показала, что 110 чел. остро нуждаются в материальной помощи. Решением бюро РК ВКП(б) и райисполкома трем инвалидам оказана помощь в приобретении коров.

В Рубцовске было 538 инвалидов Отечественной войны, из них работало и обучалось 328 чел. Инвалидам оказана материальная помощь, 98 чел. получили 31732 руб., много продуктов и промтоваров. 48 секретарей райкомов ВКП(б) заявили на пленуме обкома о проделанной работе [1, с. 322-324].

В Томской области на 1 января 1945 г. из стоящих на учете 9345 инвалидов было трудоустроено почти $92 \%$. В системе Наркомата социального обеспечения РСФСР работало 22 дома отдыха и 4 санатория, в которых инвалиды войны поддерживали свое здоровье [2, с. 92, 94]. 
Таким образом, Советское государство заботилось о солдатах и командирах Красной армии, которые отдали свои силы и здоровье в борьбе за свободу и независимость Родины. Помощь государства приумножалась всенародной поддержкой трудящихся. Эвакуированные в Западную Сибирь госпитали были размещены в лучших помещениях, обеспечивались передовым в то время оборудованием, укомплектованы высококвалифицированными медицинскими кадрами. Рабочие, служащие предприятий, организаций и учреждений, принявшие шефство над госпиталями, организовывали различные мероприятия для помощи раненым и больным воинам и инвалидам. Женщины обустраивали быт раненых, дежурили у тяжелобольных, были донорами - отдавали бесплатно свою кровь. Рабочие и служащие проводили воскресники и декадники, чтобы заработанные, а также собранные среди населения деньги, использовать на оказание единовременной помощи, подготовить и вручить подарки каждому воину и инвалиду к знаменательным датам. При госпиталях были организованы курсы и мастерские, где инвалиды войны обучались различным специальностям, а органы социальной помощи способствовали трудоустройству. Выздоравливающие в госпиталях воины совершенствовали свою боевую и политическую подготовку для возвращения на фронт.

\section{Список использованной литературы}

1. Алтай в годы Великой Отечественной войны : сб. док. и материалов / под ред. Е. В. Заруцкой. - Барнаул : Алт. кн. изд-во, 1965. - 455 с.

2. Васильев Ю. А. Коммунистическая партия - организатор патриотического движения трудящихся Сибири по оказанию материальной помощи фронту / Ю. А. Васильев. - Тюмень : Тюм. кн. изд-во, 1963. - 132 с.

3. История Великой Отечественной войны Советского Союза. 1941-1945. / под ред. П. Н. Поспелова. - М. : Воениздат, 1961. - T. 2. -682 c. 
4. Омская партийная организация в первый период Великой Отечественной войны (июнь 1941 - ноябрь 1942 г.). В 2 т. : сб. док. и материалов / И. Д. Клеткин [и др.]. - Омск : Кн. издво, 1960. - Т. 1. - 264 с.

5. Омская партийная организация в период коренного перелома и окончательной победы над врагом : сб. док. и материалов / И. Д. Клеткин [и др.]. - Омск : Кн. изд-во, 1961. T. 2. $-304 \mathrm{c}$.

6. Семенов М. А. Фронт в тылу: система здравоохранения в Западной Сибири в годы Великой Отечественной войны / М. А. Семенов. - Новосибирск : И-т Истории СО РАН, 2017. - 330 c.

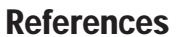

1. Zarutskaya E. V. Altai $v$ gody Velikoi Otechestvennoi voiny [Altai during the Great Patriotic War]. Barnaul, Altaiskoe knizhnoe izdatel'stvo Publ., 1965. 455 p.

2. Vasilev Yu. A. Kommunisticheskaya partiya - organizator patrioticheskogo dvizheniya trudyashchikhsya Sibiri po okazaniyu material'noi pomoshchi frontu [Communist party-organizer of the patriotic movement of workers of Siberia for providing material assistance to the front]. Tyumen, Knizhnoe izdatel'stvo Publ., 1963. $132 \mathrm{p}$.

3. Pospelov P. N. Istoriya Velikoi Otechestvennoi voiny Sovetskogo Soyuza. 1941-1945 [The history of the Great Patriotic War of the Soviet Union. 1941-1945]. Moscow, Voenizdat Publ., 1961, vol. 2. $682 \mathrm{p}$.

4. Kletkin I. D., Markova T. T., Sadovskaya V. F., Shlevko G. (eds). Omskaya partiinaya organizatsiya v peroyi period Velikoi Otechestvennoi voiny (iyun' 1941 - noyabr' 1942 g.) [Omsk party organization in the first period of the Great Patriotic War (June 1941 - November 1942)]. Omsk, Knizhnoe izdatel'stvo Publ., 1960, vol. 1. 264 p.

5. Kletkin I. D., Markova T. T., Sadovskaya V. F., Shlevko G. (eds). Omskaya partiinaya organizatsiya $v$ period korennogo pereloma $i$ okonchatel'noi pobedy nad vragom [Omsk party organization during the inflection point and the final victory over the enemy]. Omsk, Knizhnoe izdatel'stvo Publ., 1961, vol. 2. 304 p.

6. Semenov M. A. Front $v$ tylu: sistema zdravookhraneniya $v$ Zapadnoi Sibiri $v$ gody Velikoi Otechestvennoi voiny [Homefront: health care system in Western Siberia during the Great Patriotic War]. Novosibirsk, Institute of history SB RAS Publ., 2017. $330 \mathrm{p}$. 


\section{Инфрормация об авторе}

Савицкий Иван Михайлович - доктор исторических наук, главный научный сотрудник Института истории Сибирского отделения Российской академии наук. Российская Федерация, 630090, г. Новосибирск, ул. Николаева, 8.

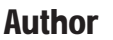

Ivan M. Savitskiy - D.Sc. in History, Senior Research Officer, Institute of History Siberian Branch of RAS, 8, Nicolaev str., Novosibirsk, 630090, Russian Federation.

\section{Для цитирования}

Савицкий И. М. Мобилизация общественного потенциала рабочих и служащих Западной Сибири по реабилитации раненых воинов Красной армии в годы Великой Отечественной войны / И. М. Савицкий / / Историко-экономические исследования. - 2018. - Т. 19, № 1. - С. $133-$ 151. - DOI: 10.17150/2308-2588.2018.19(1).133-151.

\section{$47: 4 \sin ^{3}$}

Savitskiy I. M. Mobilization of the Social Potential of Workers and Employees of Western Siberia for the Rehabilitation of Wounded Soldiers of the Red Army during the Great Patriotic War. Istoriko-ekonomicheskie issledovaniya $=$ Journal of Economic History \& History of Economics, 2018, vol. 19, no. 1, pp. 133-151. DOI: 10.17150/2308-2588.2018.19(1).133-151. (In Russian). 